\title{
Doubling Farmers Income through Adoption of High Yielding Megha Turmeric-1 in Kokrajhar District of Assam, India
}

\author{
Sanchita Brahma ${ }^{1 *}$, Manoj Kr. Bhuyan², Poran Kishore Dutta ${ }^{3}$, \\ Mahadev Uzir Basumatary ${ }^{4}$ and Goutom Bhagawati ${ }^{2}$ \\ ${ }^{1}$ Department of Horticulture, SCSCA, AAU, Dhubri, Assam, India \\ ${ }^{2}$ KVK, Kokrajhar, AAU, Gossaigaon, India \\ ${ }^{3} K V K, A A U$, Chirang, Kajalgaon, Assam, India \\ ${ }^{4} R A R S, A A U$, Gossaigaon, Assam, India \\ *Corresponding author
}

\section{A B S T R A C T}

\section{Keywords}

Turmeric, productivity, TSP, Economics,

Kokrajhar,

Doubling farmer's income

\section{Article Info}

Accepted:

10 July 2020

Available Online:

10 August 2020

\begin{abstract}
Turmeric variety Megha Turmeric-1 was introduced among the farming community of Kokrajhar district through farmers participatory mode for enhancing and doubling farmer's income under Tribal Sub Plan. A total of seven demonstrations were conducted during 2017-18 in Bhaoragaja village of Alangi under Gossaigaon sub-division for disseminating the scientific production technology of high yielding ( $270 \mathrm{q} / \mathrm{ha})$ Megha Turmeric-1 variety having high curcumin content $(6.8 \%)$. Training programmes, farmer's scientist interactions, regular surveys, monitoring of pest and diseases, diagnostic visits, advisory services etc. ensured scientific management practices viz., application of balance and optimum doses of fertilizers, timely distribution of input for pest and disease management ensured higher yield in Megha Turmeric-1. Megha Turmeric-1 recorded an average fresh rhizome yield of $205.35 \mathrm{q} / \mathrm{ha}$ with an average gross profit of Rs. 3,08,025.00/ha, net profit of Rs. 2,28,025.00/ha and B:C ratio of 3.85. With demonstration of scientific technology through farmer's participatory mode, it could be shown that yield potential and net income from high yielding turmeric cultivation could be enhanced to a great extent resulting in doubling of farm income in tribal dominated areas of Kokrajhar district.
\end{abstract}

\section{Introduction}

Turmeric (Curcuma longa L.) is an ancient, most valuable and sacred spice of India since time immemorial. It is widely used in ceremonies and religious functions and hold a place of honour in Indian traditional ayurvedic medicine. Turmeric is extensively used as stimulant, blood purifier, tonic as carminative and remedy against skin diseases, pain and anthelmintic (Sirmal, 1997). It is an erect, herbaceous perennial belonging to the family Zingiberaceae and native to South East Asia (Chickarmane et al., 2003). Locally grown varieties like Bombay Red is indigenous to the state, but it has low yield potential with low curcumin content coupled with susceptibility to leaf spot and leaf blotch disease which limits its yielding ability and commercial cutivation. A new variety 
developed by the Indian Council of Agricultural Research (ICAR) Complex for NEH Region, Meghalaya through clonal selection form Lakadong. This variety, known as Megha Turmeric-1 takes 300 to 315 days for crop maturity. The average yield of rhizome per clump is $350-425 \mathrm{~g}$ with yield potential of $270 \mathrm{q} / \mathrm{ha}$. It contained $16.37 \%$ dry matter, $6.8 \%$ curcumin and $5.5 \%$ essential oil and highly tolerant to leaf spot and leaf blotch diseases (Yadav et al., 2009). According to Anandaraj et al., (2014), Mega Turmeric-1 has showed high stability for dry yield across environments and could serve as a good genetic source for stability in breeding programs for high dry yield and curcumin content.

The agro-ecological condition of Kokrajhar district provides immense opportunity for the commercial exploitation of different horticultural crops. Moreover the district shares the international border with Bhutan in the North and state boundary with the West Bengal in the west, which offers ample opportunity for marketing of horticultural crops. Among the horticultural crops, spices particularly turmeric found an integral space in the socio-economic life of the tribal farmers of Kokrajhar district and each and every household is intimately associated with the cultivation of turmeric.

However, non-availability of quality seed material of turmeric was one of the important bottlenecks in expansion of area under commercial cultivation, which ultimately hamper production and productivity of the crop. So, to gear up commercial cultivation by the tribal farmers in the district, increase in availability of quality planting material (Megha Turmeric-1) is need of hour for tapping the available potential in turmeric trade. Production of turmeric through farmers' participatory mode is way ahead to fulfil the fast growing demand for quality turmeric seed from various stakeholders. This will not only provide scope for creation of employment opportunity but also motivates in development of entrepreneurship among tribal farmers of the district.

\section{Materials and Methods}

With intensive survey and village level meetings with headman of village, the interested farmers groups (SHGs and FC) were identified for turmeric cultivation at Bhaoragaja village of Alangi under Gossaigaon subdivision of Kokrajhar district during 2016-17. The details about scientific turmeric cultivation practices, its importance and potential of the selected area were discussed with Self Help Groups (SHGs). Hands on trainings were organized for the selected SHGs. Regular surveys, monitoring of pest \& diseases, diagnostic visit, advisory services, timely input of pest \& diseases as and when needed and ensured adoption of scientific management practices of the crop by the farmers. Total seven $\mathrm{SHGs} / \mathrm{FC}$ involving 80 farmers were selected for scientific cultivation of turmeric (Megha Turmeric-1) variety through farmers participatory mode. Total seed material @ 18 $\mathrm{q} /$ ha were distributed to SHGs for turmeric cultivation on 1.0 ha area. The details of the SHGs/FC involved in turmeric cultivation and the area covered is depicted in Table 1.

Scientific management practices for turmeric recommended in the package of practices for horticultural crops (2015) given by AAU, Jorhat, Assam were followed. The land was ploughed 4-5 times to bring the soil into fine tilth and raised beds of about $15 \mathrm{~cm}$ height, $1 \mathrm{~m}$ breadth and of convenient length were made. The turmeric rhizomes were planted in the raised bed at a spacing of $40 \mathrm{~cm}$ between ridges and $25 \mathrm{~cm}$ within ridges during AprilMay. FYM @ 20 t/ha was applied at the time of bed preparation followed by N: P: K @ 30: $50: 60 \mathrm{Kg} / \mathrm{ha}$. Half of $\mathrm{K}_{2} \mathrm{O}$ and full doses or FYM and $\mathrm{P}_{2} \mathrm{O}_{5}$ were applied as basal. Half of 
$\mathrm{N}$ and the remaining half of $\mathrm{K}_{2} \mathrm{O}$ were side dressed at first earthing up (3 months after planting) and the remaining half of $\mathrm{N}$ were dressed at second earthing up (4 months after planting). First mulching was done immediately after planting and repeated at 40 days after planting with suitable mulching material like paddy husk and saw dust, straw, green leaves etc. First weeding was done at 40 days after planting (before second mulching) and repeated depending upon intensity of weed growth at fortnightly intervals. The crop was ready for harvesting after 8-9 months of planting (Dec-Jan). Observation on fresh turmeric yield (q) and productivity (q/ha) were recorded at farmers field locations. The cost of cultivation of was worked out considering the cost of different inputs viz., planting material, FYM, fertilizers, agrochemicals and labour incurred by the SHGs/FC during the time of turmeric cultivation. Similarly, gross return, net return and $\mathrm{B}: \mathrm{C}$ ratio were calculated on the basis of price of fresh turmeric rhizome prevailing in the market @ Rs.15/kg.

\section{Results and Discussion}

An average of $22.93 \mathrm{q}$ of fresh turmeric rhizomes (Table 2) were produced from 1.0 bigha area with an average productivity of $171.95 \mathrm{q} / \mathrm{ha}$ by SHGs under participatory mode. Among the SHGs highest productivity was recorded by Laijaw SHG (205.35 q/ha) followed by Memory SHG (195.23 q/ha) and Daimalu jwhwalo FC (177.53 q/ha), while lowest productivity was recorded by Hainary SHG (136.80 q/ha). The variation in results may be due to prevailing agro-climatic condition of the location and different adoption level of scientific management practices by the SHGs.

The returns earned by SHGs/FC is depicted in Table 3 which showed that the mean average cost of turmeric cultivation per ha was Rs. $81,077.86 /$ ha with gross and net return of Rs. 2, 57, 918.57 /ha and Rs. 1,76,840.71/ha, respectively. The mean average $\mathrm{B}$ : $\mathrm{C}$ ratio of 3.18 was also recorded. The result (Table 3) showed the performance of selected SHGs in adoption of commercial cultivation of Megha Turmeric-1. Among the SHGs, highest gross return (Rs. 3,08,025.00/ha), net return (Rs. 2,28,025.00/ha) and $\mathrm{B}: \mathrm{C}$ ratio (3.85) was recorded by Laijaw SHG, closely followed by Memory SHG (gross return of Rs. 2,92,845.00/ha, net return of Rs. $2,12,845.00 /$ ha and $\mathrm{B}: \mathrm{C}$ ratio of 3.66 , respectively) and Daimalu Jwhwalo FC (gross return of Rs. 2,66,295.00/ha, net return of Rs. $1,81,975.00 /$ ha and $\mathrm{B}$ : $\mathrm{C}$ ratio of 3.16 , respectively).

Table.1 List of SHGs/FC involved in the turmeric cultivation

\begin{tabular}{|l|l|l|l|}
\hline Sl. No. & Name of SHGs/FC & Name of Village & Area (ha) \\
\hline $\mathbf{1 .}$ & Memory SHG & Bhaoragwja, Alangi & 0.13 \\
\hline 2. & Geremsha SHG & Bhaoragwja, Alangi & 0.13 \\
\hline $\mathbf{3 .}$ & Hainary SHG & Bhaoragwja, Alangi & 0.13 \\
\hline $\mathbf{4 .}$ & Laijaw SHG & Bhaoragwja, Alangi & 0.13 \\
\hline $\mathbf{5 .}$ & Jwogakang FC & Bhaoragwja, Alangi & 0.13 \\
\hline 6. & Jakangpu FC & Bhaoragwja, Alangi & 0.13 \\
\hline 7. & Daimalu jwhwlao FC & Bhaoragwja, Alangi & 0.22 \\
\hline & Total & & $\mathbf{1 . 0}$ ha \\
\hline
\end{tabular}


Table.2 Realization of Turmeric yield (var. Megha Turmeric-1) by the different SHGs

\begin{tabular}{|l|l|c|c|}
\hline Sl. No. & Name of SHG/FC & $\begin{array}{c}\text { Fresh Rhizome Yield } \\
\text { (q/bigha) }\end{array}$ & $\begin{array}{c}\text { Productivity } \\
\text { (q/ha) }\end{array}$ \\
\hline $\mathbf{1 .}$ & Memory SHG & 26.03 & 195.23 \\
\hline $\mathbf{2 .}$ & Geremsha SHG & 22.82 & 171.15 \\
\hline $\mathbf{3 .}$ & Hainary SHG & 18.24 & 136.80 \\
\hline $\mathbf{4 .}$ & Laijaw SHG & 27.38 & 205.35 \\
\hline $\mathbf{5 .}$ & Jwogakang FC & 20.89 & 156.68 \\
\hline $\mathbf{6 .}$ & Jakangpu FC & 21.45 & 160.88 \\
\hline 7. & Daimalu jwhwlao FC & 23.67 & 177.53 \\
\hline & Total/Mean & $\mathbf{2 2 . 9 3}$ & $\mathbf{1 7 1 . 9 5}$ \\
\hline
\end{tabular}

Table.3 Returns earned by SHGs through Turmeric cultivation by participatory mode

\begin{tabular}{|l|l|c|c|c|c|}
\hline Sl. No. & Name of SHG/FC & $\begin{array}{c}\text { Cost of Cultivation } \\
\text { (Rs./ha) }\end{array}$ & $\begin{array}{c}\text { Gross Return } \\
\text { (Rs./ha) }\end{array}$ & $\begin{array}{c}\text { Net Return } \\
\text { (Rs./ha) }\end{array}$ & B:C ratio \\
\hline 1. & Memory SHG & $80,000.00$ & $2,92,845.00$ & $2,12,845.00$ & 3.66 \\
\hline 2. & Geremsha SHG & $82,675.00$ & $2,56,725.00$ & $1,74,050.00$ & 3.10 \\
\hline 3. & Hainary SHG & $78,650.00$ & $2,05,200.00$ & $1,26,550.00$ & 2.61 \\
\hline $\mathbf{4 .}$ & Laijaw SHG & $80,000.00$ & $3,08,025.00$ & $2,28,025.00$ & 3.85 \\
\hline $\mathbf{5 .}$ & Jwogakang FC & $81,400.00$ & $2,35,020.00$ & $1,53,620.00$ & 2.89 \\
\hline 6. & Jakangpu FC & $80,500.00$ & $2,41,320.00$ & $1,60,820.00$ & 3.00 \\
\hline 7. & Daimalu Jwhwlao FC & $84,320.00$ & $2,66,295.00$ & $1,81,975.00$ & 3.16 \\
\hline & Total/Mean & $\mathbf{8 1 , 0 7 7 . 8 6}$ & $\mathbf{2 , 5 7 , 9 1 8 . 5 7}$ & $\mathbf{1 , 7 6 , 8 4 0 . 7 1}$ & $\mathbf{3 . 1 8}$ \\
\hline
\end{tabular}

The Hainary SHGs produced the lowest gross return, net return as well as the lowest B: C ratio among all SHGs.

The difference in monitory return among the selected SHGs and FC may be due to variation in adoption of scientific management practices on time by the SHGs and FC. The technological intervention (Megha Turmeric -1 and scientific management practices) provided by KVK, Kokrajhar helps to achieve higher returns to SHGs. With this success, several farmers from the nearby villages are coming forward for adoption of turmeric cultivation in a scientific method. Production of turmeric through participatory mode under Tribal Sub Plan increased the availability of high yielding quality planting material of turmeric to SHGs as well as to the nearby farmers for next year of planting. It helped in reduction in cost incurred on purchase of planting material and ultimately reduced the cost of cultivation. Introduction of Megha Turmeric-1 in the tribal dominated areas under TSP not only made the farmers aware about the variety but also helped to increase farm income for the SHGs along with other income generating enterprises by way of doubling farm income.

In conclusion the good agricultural practices of Megha Turmeirc-1 as demonstrated in Gossaigaon sub-division of Kokrajhar district by KVK, Kokrajhar through farmers' participatory mode during 2016-17 under tribal sub plan helped in commercialization of the turmeric variety among the farming community of the district. Adoption of 
scientific commercial production paved the way for doubling farm income, which lead to productivity enhancement from $17-20$ t/ha with $\mathrm{B}$ : C ratio of 3.85 .

\section{References}

Anandaraj M, Prasath D, Kandiannan K, Zachariah T J, Jha A K, Singh B K, Singh A K, Pandey V P, Singh S P, Shoba N, Jana J C, Ravindra K K and Uma Maheshwari K. (2014). Genotype by environment interaction effects on yield and curcumin in turmeric (Curcuma longa L.). Industrial Crops and Products 53:358364.
Chickarmane, S., Rehse, T. and Prayer, K.M (2003). Tracing the cultural and botanical origins of turmeric (Curcuma longa L.). Poster. Botany conf.org.in

Singh G. (2010). Blooming horticultural revolution in north eastern region. Indian Horticulture, ICAR, New Delhi, Pp 10-14.

Srimal, R.C. (1997). Turmeric: a brief review of medicinal properties. Fitoterapia 68 (6): 483-93.

Yadav R.K., Sanwal S.K., Deka B.C., Ngachan S.V., Sarma P., and Buragohain J. (2009). Vegetable improvement in north eastern region. ICAR-RC-NEH Region, Umiam, Meghalaya. 70:76 -80.

\section{How to cite this article:}

Sanchita Brahma, Manoj Kr. Bhuyan, Poran Kishore Dutta, Mahadev Uzir Basumatary and Goutom Bhagawati. 2020. Doubling Farmers Income through Adoption of High Yielding Megha Turmeric-1 in Kokrajhar District of Assam, India. Int.J.Curr.Microbiol.App.Sci. 9(08): 631-635. doi: https://doi.org/10.20546/ijcmas.2020.908.070 